\title{
MENGENAL PASAR MODAL
}

Tentang Penulis

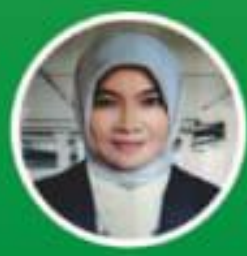

Tine Badriatin, S.Sos., M.Si. Kelahiran Kota Tasikmalaya dimana saat ini merupakan Kepala Kantor Perwakilan Tasikmalaya PT. Reliance Sekuritas Indonesia, Tbk dan juga merupakan Dosen Praktisi Prodi Keuangan dan Perbankan, Fakultas Ekonomi dan Bisnis Universitas Siliwangi Tasikmalaya pengampu mata kuliah Pasar Modal dan Lab Praktika Pasar Modal. Pemegang License SertifikasiWPPEPasar Modal dan License BNSP Digital Marketing.

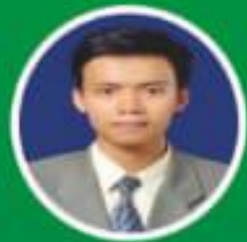

Agi Rosyadi, S.E., M.M. Kelahiran Tasikmalaya 15 Maret 1991, Merupakan Dosen Prodi Keuangan dan Perbankan, Fakultas Ekonomi dan Bisnis Universitas Siliwangi Tasikmalaya. Memiliki Jabatan Fungsional sebagai Asisten Ahli dan juga pengampu mata kuliah Bank dan Lembaga Keuangan Lainnya Syariah, Interpersonal Skill, Manajemen Pemasaran Bank, Teknologi Administrasi Bank, Praktika Manajemen Pemasaran Bank.

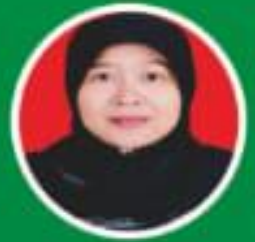

Mira Rahmawati, S.P., M.M. Kelahiran Jakarta, 7 Juli 1983, Merupakan Dosen Prodi Keuangan dan Perbankan, Fakultas Ekonomi dan Bisnis Universitas Siliwangi Tasikmalaya. Memiliki Jabatan Fungsional sebagai Asisten Ahli dan juga pengampu mata kuliah Matematika Keuangan, Perpajakan, Pasar Modal, Pengantar Bisnis, Komunikasi Bisnis, Pengantar Ekonomi Makro, Pengantar Ekonomi Mikro.

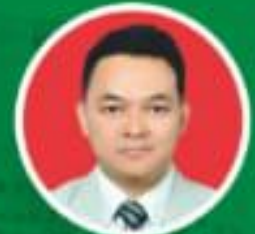

R. Lucky Radi Rinandiyana, S.E., M.Si. Kelahiran Kota Tasikmalaya, Merupakan Dosen Tetap Prodi S-1 Manajemen, Fakultas Ekonomi dan Bisnis Universitas Siliwangi Tasikmalaya. Memiliki Jabatan Akademik sebagai Lektor dan juga pengampu mata kuliah Manajemen Pemasaran 1 dan 2. Manajemen Operasional 1 dan 2, Manajemen Mutu Terpadu, Perencanaan dan Pengendalian Produk, Pasar Modal. Pemegang License Sertifikasi WPPE-P, Asesor Kompetensi BNSP, Sertifikat Kompetensi Kewirausahaan Industri dari Badan Nasional Sertifikasi Profesi (BNSP), Sertifikasi BNSP Digital Marketing.

Buku ini dibuat untuk dapat lebih mengenalkan Pasar Modal khususnya di kalangan para mahasiswa untuk mengenal dan mendapatkan pengetahuan mengenai pasar modal sejak dini, sehingga para Mahasiswa mampu memahami bagaimana berinvestasi di pasar modal.

Buku merupakan jembatan ilmu, salah satu kunci kesuksesan adalah berawal dari kemauan untuk belajar dimana kemauan tersebut perlu ditunjang oleh berbagai sarana diantaranya adalah buku. Buku ini dihasilkan oleh satu tim orang-orang yang menjadi bagian dari tim pengajar pasar modal, dan yang persahabatannya kami hargai sangat tinggi. Dalam kesempatan inikamijuga mengucapkan terima kasih kepada seluruh pihak yang telah membantu dalam penyusunan bukuini.

Editor : Lucky Radi Rinandiyana
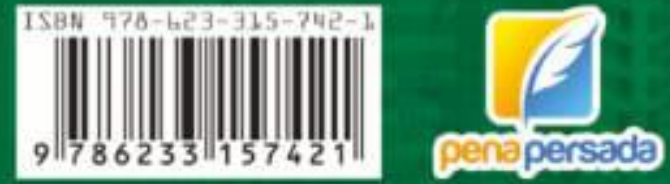

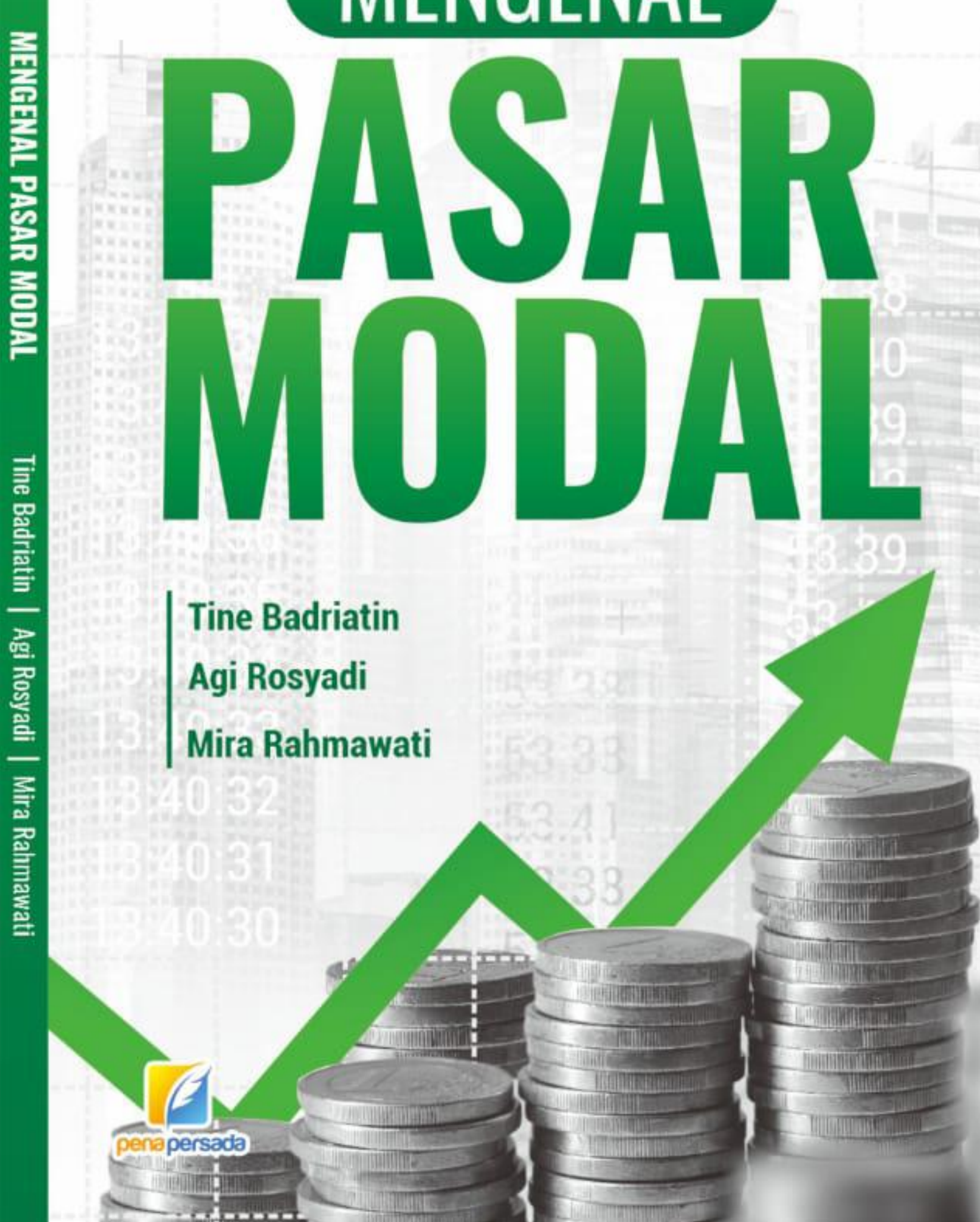




\title{
MENGENAL PASAR MODAL
}

\author{
Tine Badriatin \\ Agi Rosyadi \\ Mira Rahmawati
}

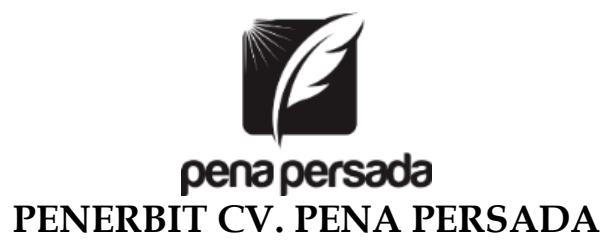




\title{
MENGENAL PASAR MODAL
}

\author{
Penulis: \\ Tine Badriatin \\ Agi Rosyadi \\ Mira Rahmawati
}

ISBN: 978-623-315-742-1

Editor :

Lucky Radi Rinandiyana

\section{Desain Cover:}

Retnani Nur Brilliant

\section{Layout:}

Dita Nurul Aviqoh

\section{Penerbit CV. Pena Persada \\ Redaksi:}

Jl. Gerilya No. 292 Purwokerto Selatan, Kab. Banyumas Jawa Tengah

Email: penerbit.penapersada@gmail.com Website: penapersada.com Phone: (0281) 7771388

\section{Anggota IKAPI}

All right reserved

Cetakan pertama: 2021

Hak Cipta dilindungi oleh undang-undang. Dilarang memperbanyak karya tulis ini dalam bentuk apapun tanpa izin penerbit 


\section{KATA PENGANTAR}

Puji syukur kami panjatkan ke hadirat Allah SWT atas rahmat dan karunia-Nya kami bisa menyelesaikan penyusunan buku "Mengenal Pasar Modal" ini, tidak lupa shalawat dan salam kita haturkan ke jungjunan alam Nabi Muhammad SAW. Buku ini dibuat untuk dapat lebih mengenalkan Pasar Modal khususnya di kalangan mahasiswa sebagai generasi muda. Harapan kami dalam penyusunan buku ini dapat membantu para mahasiswa untuk mengenal dan mendapatkan pengetahuan mengenai pasar modal sejak dini, sehingga para Mahasiswa mampu memahami bagaimana berinvestasi di pasar modal.

Buku merupakan jembatan ilmu, salah satu kunci kesuksesan adalah berawal dari kemauan untuk belajar dimana kemauan tersebut perlu ditunjang oleh berbagai sarana diantaranya adalah buku. Buku ini dihasilkan oleh satu tim orang-orang yang menjadi bagian dari tim pengajar pasar modal, dan yang persahabatannya kami hargai sangat tinggi. Dalam kesempatan ini kami juga mengucapkan terima kasih kepada seluruh pihak yang telah membantu dalam penyusunan modul ini.

Kami menyadari bukul ini masih ada kekurangan dan ketidaksempurnaan oleh karena itu kami terbuka untuk menerima kritik dan saran demi perbaikan dimasa yang akan datang.

Tasikmalaya, Septembr 2021

Penyusun 


\section{DAFTAR ISI}

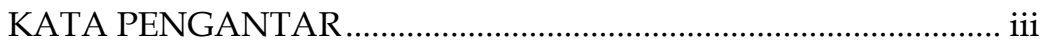

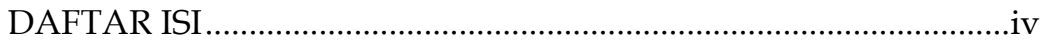

BAB 1 PENGENALAN PASAR MODAL .....................................

A. Pengertian Pasar Modal ......................................................... 1

B. Manfaat Pasar Keuangan (Finansial Market) ............................ 3

C. Peran Pasar Modal dalam Kegiatan Investasi dan

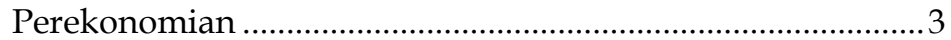

D. Fungsi Pasar Modal...............................................................

E. Peranan Pasar Modal pada Suatu Negara ................................. 4

F. Kode Etik \& Standar Profesional Pasar Modal .......................... 5

BAB 2 STRUKTUR PASAR MODAL .............................................

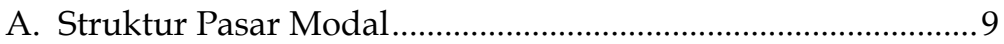

B. Self Regulatory Organizations (SRO) ………..........................16

BAB 3 MEKANISME PERDAGANGAN ………........................18

A. Gekanisme Perdagangan di Pasar Perdana .............................18

B. Mekanisme Perdagangan di Pasar Sekunder..........................28

C. Proses Transaksi di Pasar Sekunder...........................................32

D. Hubungan Investor dan Pialang (Broker)................................33

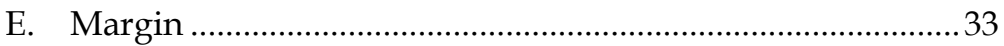

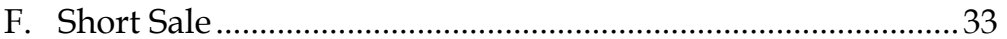

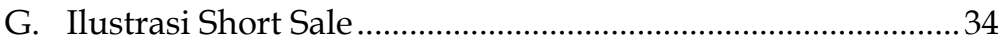

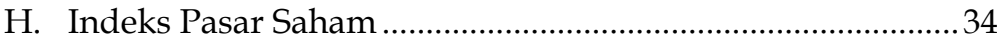

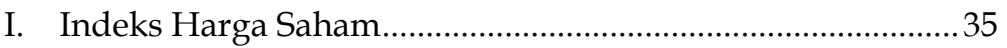

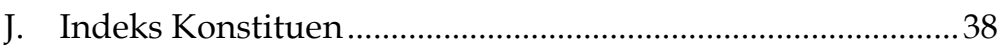

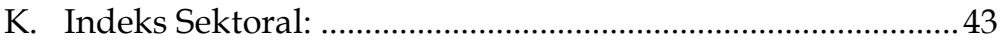

BAB 4 RISK AND RETURN PASAR MODAL .............................46

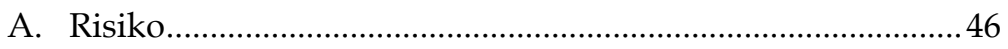

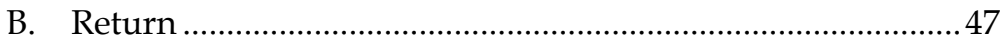

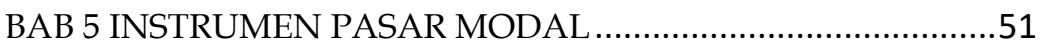

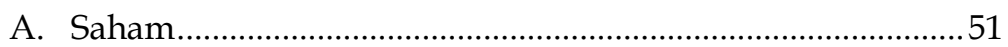

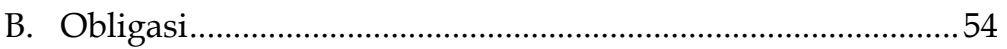

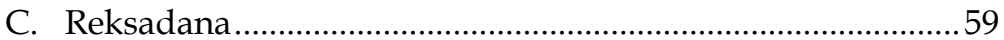

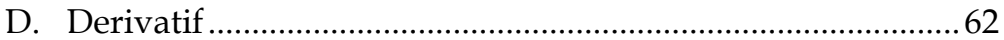

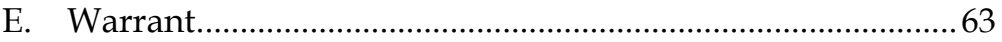


BAB 6 MANAJEMEN PORTOFOLIO DAN ANALISA INVESTASI

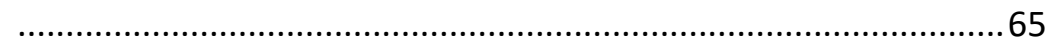

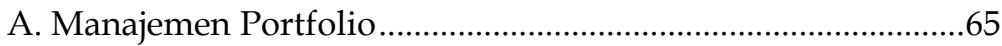

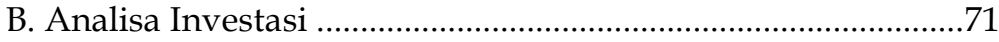

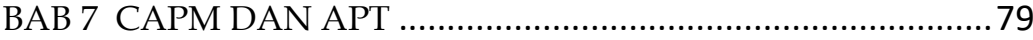

A. Capital Asset Pricing Model (CAPM) .....................................79

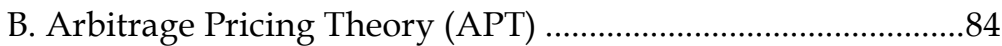

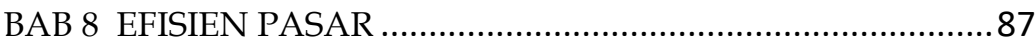

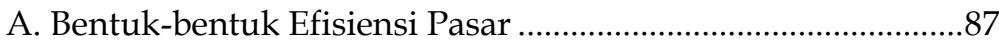

B. Wipotesis Pasar yang Efisien......................................................91

C. Pengujian Hipotesis Pasar yang Efisien ……............................91

D. Implikasi Pasar Modal yang Efisien .........................................95

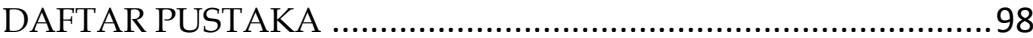


MENGENAL PASAR MODAL 


\section{BAB 1 \\ PENGENALAN PASAR MODAL}

Adanya pandemi Covid-19 masih mengakibatkan gejolak pasar yang terus berlanjut di tahun 2021. Dampaknya sangat terasa dalam kinerja Indeks Harga Saham Gabungan (IHSG) dimana pada Triwulan pertama mencatatkan kinerja negatif sebesar $-1,79 \%$ ke level 5.996. Dimana penurunan paling dalam dari sektor Properti dan Manufaktur menjadi sektor penyumbang penuruna terbesar yaitu $12,39 \%$ dan $12,36 \%$ dan penurunan IHSG terdalm $-4,11 \%$ pada bulan Maret 2021.

Meskipun adanya kekhawatiran pasar financial namun kebuthan dunia usaha terhadap permodalan cenderung menunjukkan jumlah yang semakin bertambah. Oleh karena itu untuk memudahkan masyarakat dan produsen dalam mendapatkan permodalan maka pemerintah bersama-sama lembaga ekonomi menyelenggarakan kegiatan pasar modal.

\section{A. Pengertian Pasar Modal}

Pasar Modal merupakan salah satu jenis dari Pasar Keuangan (Finansial Market). Pasar Keuangan (Finansial Market) adalah pasar yang memperjual belikan instrumen-instrumen keuangan. Mekanisme dimana peminjam-peminjam bertemu dan melakukan jual dan beli instrumen keuangan. Pasar keuangan terdiri dari:

1. Money Market (Pasar Uang)

Pasar yang memperdagangkan asset keuangan dalam jangka pendek ( $<1$ tahun) Contoh call money, interbank loan dan valas.

2. Capital Market (Pasar Modal)

Pasar yang memperdagangkan asset keuangan dalam jangka panjang (> 1 tahun), contoh saham, obligasi, dan produk derivatif.

Pasar modal (capital market) adalah lembaga keuangan bukan bank yang mempunyai kegiatan berupa penawaran dan perdagangan efek. Selain itu juga merupakan lembaga 
profesi yang berkaitan dengan transaksi jual beli efek dan perusahaan publik yang berkaitan dengan efek. Dalam pasar modal atau bursa efek dikenal istilah Investor dan Emiten dimana Investor adalah pemodal, yaitu individu atau lembaga/perusahaan yang mempunyai modal atau dana untuk dipinjamkan. Sedangkan Emiten adalah individu atau perusahaan yang melakukan penawaran umum dimana Penawaran umum adalah penawaran untuk menjual efek atau saham oleh emiten kepada masyarakat luas atau publik. Dengan demikian pasar modal dikenal juga sebagai tempat bertemunya penjual dan pembeli modal atau dana.

Pasar modal merupakan sarana bagi perusahaan:

1. Untuk mendapatkan modal dari masyarakat luas. Pasar modal memberikan peluang bagi perusahaan untuk memperoleh sumber dana yang relaif memiliki risiko investasi (cost of capital) rendah dibandingkn dengan sumber dana jangka pendek dari pasar uang, karena mengambil sumber dana dari pasar uang (contohnya kredit perbankan) terdapat cost of capital berupa angsuran pokok dan bunga secara periodik.

2. Untuk pemerataan kepemilikan perusahaan oleh masyarakat. dengan adanya pasar modal, memberikan peluang bagi masyarakat untuk mendapatkan kepemilikan atas suatu perusahaan sesuai dengan proporsi saham yang dimilikinya, dari investasinya tersebut akan berujung pada peningkatan kesejahteraan masyarakat yang bersangkutan

3. Untuk keterbukaan informasi perusahaan. Sejalan dengan keterbukaan informasi perusahaan, dari perusahaan yang telah go public dapat diperoleh evaluasi terhadap nilai perusahaan. Setiap peningkatan kinerja operasional dan kinerja keuangan akan memiliki dampak terhadap harga saham, yang pada akhirnya akan meningkatkan nilai perusahaan 


\section{B. Manfaat Pasar Keuangan (Finansial Market)}

1. Alternatif Investasi

Melalui pasar keuangan investor dapat menghasilkan yield (hasil) atas aktivitas investasi.

2. Alternatif Pendanaan

Bagi perusahaan yang membutuhkan dana, pasar keuangan dapat menjadi sumber pendanaan.

\section{Peran Pasar Modal dalam Kegiatan Investasi dan Perekonomian}

1. Pasar modal mempunyai peranan penting dalam mobilisasi dana untuk menunjang pembangunan nasional.

2. Akses dana dari pasar modal telah mengundang banyak perusahaan nasional maupun patungan untuk menyerap dana masyarakat tersebut dengan tujuan yang beragam. Namun, sasaran utamanya adalah meningkatkan produktivitas kerja melalui ekspansi usaha dan mengadakan pembenahan struktur modal untuk meningkatkan daya saing perusahaan.

3. Pasar modal memiliki peran besar bagi perekonomian suatu Negara karena pasar modal memiliki dua fungsi sekaligus, yaitu:

a. Fungsi ekonomi

menyediakan fasilitas yang mempertemukan dua kepentingan yaitu pihak yang memiliki kelebihan dana (investor) dan pihak yang memerlukan dana (issuer). Dengan adanya pasar modal maka pihak yang memiliki kelebihan dana dapat menginvestasikan dana tersebut dengan harapan memperoleh imbalan (return) berupa dividen, sedangkan pihak issuer (dalam hal ini perusahaan) dapat memanfaatkan dana tersebut untuk kepentingan investasi tanpa harus menunggu tersedianya dana dari kegiatan operasi perusahaan. 
b. Fungsi keuangan

Pasar modal memberikan kemungkinan dan kesempatan bagi pemilik dana untuk memperoleh imbalan (return), sesuai dengan karakteristik investasi yang dipilih (saham, obligasi, reksadana, dll)

\section{Fungsi Pasar Modal}

Selain fungsi ekonomi dan keuangan, pasar modal juga memberikan fungsi besar bagi pihak-pihak yang ingin mendapat keuntungan dalam berinvestsi, diantaranya adalah (Hadi: 2015)

1. Bagi perusahaan. Dengan adanya pasar modal, dapat memberi peluang bagi perusahaan untuk memperoleh sumber dana dengan resiko investasi rendah jika dibanding dengan sumber dana jangka pendek dari pasar uang.

2. Bagi investor. Dengan adanya pasar modal, dapat memberi peluang bagi para investor untuk berinvestasi dan memperoleh return yang cukup tinggi

3. Bagi perekonomian nasional. Dengan adanya pasar modal, akan berperan dalam meningkatkan pertumbuhan ekonomi. Dimana akan terjadi kemudahan penyediaan dana untuk sektor riil dalam peningkatan produktifitas, sementara dari pihak investor akan memperoleh keuntungan dari dana yang dimiliki

\section{E. Peranan Pasar Modal pada Suatu Negara}

1. Sebagai fasilitas dalam melakukan interaksi antara pembeli dan penjual untuk menentukan harga saham atau surat berharga yang diperjualbelikan

2. Pasar modal memberikan kesempatan kepada investor untuk memperoleh hasil return) yang diharapkan.

3. Pasar modal memberi kesempatan kepada investor untuk menjual kembali saham yang dimilikinya atau surat berharga lainnya.

4. Pasar modal menciptakan kesempatan kepada masyarakat untuk berpartisipasi dalam perkembangan suatu perekonomian. 
5. Pasar modal mengurangi biaya informasi dan transaksi surat berharga. Bagi para investor, keputusan investasi harus didasarkan pada tersedianya informasi yang akurat dan dapat dipercaya. Pasar modal dapat menyediakan kebutuhan informasi bagi para investor secara lengkap, yang apabila hal tersebut dicari sendiri, akan memerlukan biaya yang sangat mahal.

\section{F. Kode Etik \& Standar Profesional Pasar Modal}

1. Di pasar modal ada beberapa profesi yang wajib menaati Kode Etik dan Standar Profesional Pasar Modal

2. Orang yang bisa melakukan perdagangan efek di dunia pasar modal harus memiliki kualifikasi tertentu dari Otoritas Jasa Keuangan (OJK). Kualifikasi Profesi pasar modal diharapkan dapat meningkatkan teknis profesi para pelaku pasar modal di Indonesia.

3. Para wakil pedagang efek yang sudah mendapatkan izin dari OJK antara lain WPPE (WPPE-PT, WPPE-P, WPPE), WPEE, dan WMI.

\section{WPEE}

a. Wakil Penjamin Emisi Efek atau yang biasa dikenal dengan underwriter.

b. Bertugas untuk membantu perusahaan-perusahaan yang ingin melakukan penawaran umum perdana di Bursa.

c. Jika sebuah perusahaan berencana untuk go public atau IPO (Initial Public Offering) di Bursa Efek Indonesia, maka semua proses IPO akan dikerjakan oleh underwriter.

d. Seseorang yang bersertifikasi Wakil Penjamin Emisi Efek (underwriter) juga bisa menjadi seorang broker. 


\section{WPPE}

a. WPPE yaitu Wakil Perantara Pedagang Efek, profesi pasar modal yang sering dikenal dengan istilah broker atau pialang.

b. Bertugas sebagai perantara antara investor \& Bursa Efek Indonesia dalam melakukan perdagangan efek.

c. Membantu investor dalam menilai dan merekomendasikan saham-saham pilihan.

d. Juga bertugas sebagai pemberi saran atau nasehat kepada investor ttg transaksi di pasar modal.

e. Melakukan transaksi jual dan beli sesuai perintah atau keinginan investor

f. Wakil Perantara Pedagang Efek (broker) bisa dicabut perizinannya jika melakukan pelanggaran atau menyimpang dari kode etik. Contoh: tidak jujur dalam mengelola akun nasabah atau investor. Wakil Perantara Pedagang Efek (broker) tidak boleh hanya memberikan gambaran imbal hasil investasinya saja, tetapi juga risikonya.

\section{WMI}

a. Tugas Wakil Manajer Investasi (WMI) hampir sama dengan Wakil Perantara Pedagang Efek (broker), meskipun ada perbedaannya.

b. Selain bertugas sebagai pemberi nasihat investasi, Wakil Manajer Investasi (WMI) juga berhak untuk mengelola portofolio efek dari investor. Portofolio efek dari investor yang dikelola Wakil Manajer Investasi (WMI) bisa berupa saham maupun

c. reksadana.

d. Pada umumnya, Wakil Manajer Investasi (WMI) biasa dikenal dengan perusahaan Asset Management.

4. Dalam kegiatan perdagangan Efek, setiap Pihak dilarang secara langsung atau tidak langsung (UU No. 8 tahun 1995), tentang Pasar Modal, Pasal 90 tentang Penipuan): 
a. Menipu atau mengelabui Pihak lain dengan menggunakan sarana dan atau cara apapun

b. Turut serta menipu atau mengelabui pihak lain, dan

c. Membuat pernyataan tidak benar mengenai fakta yang material, atau tidak mengungkapkan fakta yang material agar pernyataan yang dibuat tidak menyesatkan mengenai keadaan yang terjadi pada saat pernyataan dibuat dengan maksud untuk menguntungkan atau menghindarkan kerugian untuk diri sendiri atau Pihak lain atau dengan tujuan mempengaruhi pihak lain untuk membeli atau menjual efek

5. Selain itu juga dalam kegiatan efek dilarang melakukan Manipulasi Pasar (UU No. 8 th 1995, tentang Pasar Modal, pasal 90)

a. Setiap Pihak dilarang melakukan tindakan, baik langsung maupun tidak langsung, dengan tujuan untuk menciptakan gambaran semu atau menyesatkan mengenai kegiatan perdagangan, keadaan pasar, atau harga Efek di Bursa Efek.

b. Setiap Pihak, baik sendiri-sendiri maupun bersama sama Pihak lain, dilarang melakukan 2 transaksi Efek atau lebih, baik langsung maupun tidak langsung, sehingga menyebabkan harga Efek di Bursa Efek tetap, naik, atau turun dengan tujuan mempengaruhi Pihak lain untuk membeli, menjual, atau menahan Efek

c. Setiap Pihak dilarang, dengan cara apapun, membuat pernyataan atau memberikan keterangan yang secara material tidak benar atau menyesatkan sehingga mempengaruhi harga Efek di Bursa Efek

\section{Perdagangan Orang Dalam (UU No. 8 th 1995, tentang Pasar Modal, pasal 90)}

a. Orang dalam dari Emiten atau Perusahaan Publik yang mempunyai informasi orang dalam, dilarang melakukan pembelian atau penjualan atas Efek:

1) Emiten atau Perusahaan Publik dimaksud; atau 
2) Perusahaan lain yang melakukan transaksi dengan Emiten atau Perusahaan Publik yang bersangkutan

b. Orang dalam dilarang:

1) Mempengaruhi Pihak lain untuk melakukan pembelian atau penjualan atas Efek dimaksud; atau

2) Memberi informasi orang dalam kepada Pihak mana pun yang patut diduganya dapat menggunakan informasi dimaksud untuk melakukan pembelian atau penjualan atas Efek

Yang dimaksud Orang Dalam, yaitu:

1) Manajemen perusahaan (anggota Direksi, dan anggota Dewan Komisaris)

2) Pegawai Perusahaan

3) Pihak yang berhubungan langsung dengan perusahaan dalam rangka pekerjaan (KAP, Konsultan Hukum, Konsultan Manajemen, Supplier, Perusahaan Penilai, Research Analyst, dan Penjamin Emisi). 


\section{BAB 2 \\ STRUKTUR PASAR MODAL}

\section{A. Struktur Pasar Modal}

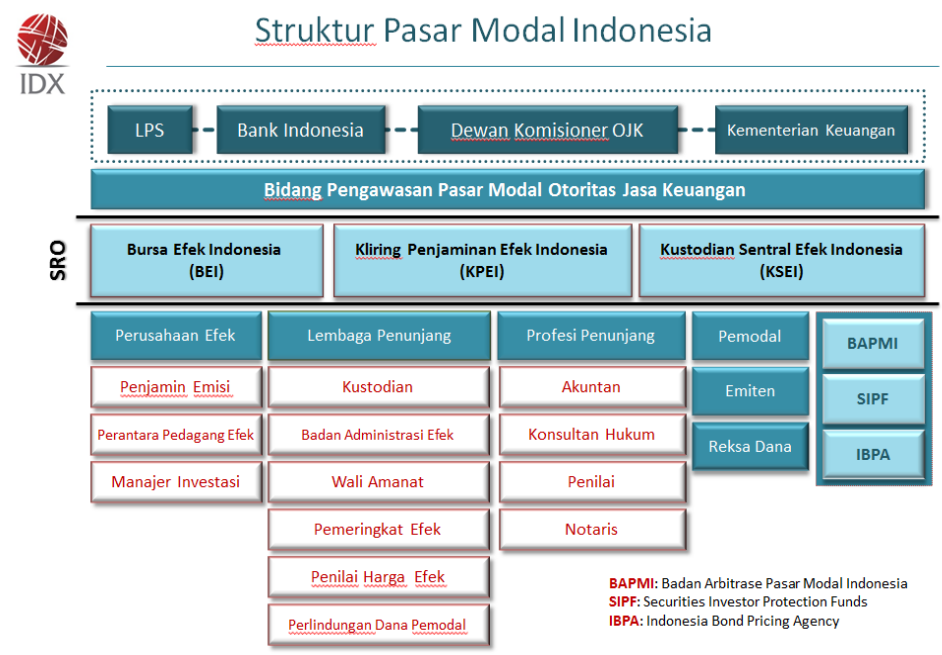

Sumber: www.idx.co.id

Keterangan:

\section{Otoritas Jasa Keuangan (OJK)}

Adalah lembaga negara yang dibentuk berdasarkan UU Nomor 21 Tahun 2011 yang berfungsi menyelenggarakan sistem pengaturan dan pengawasan yang terintegrasi terhadap keseluruhan kegiatan di dalam sektor jasa keuangan.

OJK adalah lembaga yang independen dan bebas dari campur tangan pihak lain (Self Regulator) yang mempunyai fungsi, tugas, dan wewenang pengaturan, pengawasan, pemeriksaan dan penyidikan.

OJK didirikan untuk menggantikan peran BapepamLK dalam pengaturan dan pengawasan pasar modal dan lembaga keuangan, serta menggantikan peran Bank Indonesia dalam pengaturan dan pengawasan sehingga 
dapat melakukan pengawasan yang lebih baik lagi, dan untuk melindungi konsumen industri jasa keuangan, untuk meminimalisir tindak kejahatan dalam dunia pasar modal seperti manipulasi dan lain sebagainya.

Mengapa OJK pengawasannya lebih luas? Bapepam adalah sebuah lembaga dibawah kementerian keuangan, sedangkan OJK adalah lembaga nasional yang berdiri sendiri dan tidak ada campur tangan dari pihak manapun, dan dibawah OJK ini banyak divisi-divisi lain seperti divisi pengawasan perbankan, divisi pengawasan pasar modal, divisi pengembangan pengawasan, dan masih banyak lagi (bisa dilihat di struktur organisasi OJK), tugas OJK lebih luas, karena memiliki beberapa kewenangan yang dulunya ada pada Menteri Keuangan dan BI, yang tidak dimiliki oleh Bapepam.

\section{BEI (Bursa Efek Indonesia)}

Pihak yang menyelenggarakan dan menyediakan sistem atau sarana dan prasarana untuk mempertemukan penjual dan membeli dalam perdagangan efek. Di bursa efek, saham dan obligasi serta sekuritas jangka panjang lainnya diperdagangkan antar investor. Undang-Undang No. 8 tahun 1995 tentang pasar modal mendefinisikan bursa efek adalah pihak yang menyelenggarakan dan menyediakan sistem dan sarana untuk mempertemukan penawaran jual dan beli efek pihak-pihak lain dengan tujuan memperdagangkan efek antara mereka.

Berdasarkan Undang-undang Bapepam No. 8/1995, tujuan keberadaan Bursa efek antara lain adalah untuk meyelenggarakan perdagangan efek yang teratur, wajar dan efisien serta memberikan fasilitas fisik maupun mekanisme terjadinya transaksi jual dan beli oleh investor sekuritas pasar modal dengan perantara Wakil Perantara Perdagangan efek (WPPE). Bursa efek dapat membentuk aliansi dengan bursa lain untuk meningkatkan efisiensi dan likuiditasnya. Contoh: 
Pada tanggal 30 November 2007, BEJ dan BES digabung dan berganti nama menjadi Bursa Efek Indonesia.

\section{KPEI (Kliring Penjaminan Efek Indonesia)}

PT Kliring Penjaminan Efek Indonesia (KPEI) didirikan berdasarkan Undang-Undang Pasar Modal Indonesia tahun 1995 untuk menyediakan jasa kliring dan penjaminan penyelesaian transaksi bursa yang teratur, wajar dan efisien. Sebagai pihak yang menyelenggarakan jasa kliring dan penjaminan penyelesaian transaksi bursa, tugas KPEi antara lain adalah wajib menetapkan peraturan mengenai kegiatan kliring dan penjaminan penyelesaian transaksi bursa, termasuk ketentuan mengenai baya pemakaian jasa; dan menjamin penyerahan secara fisik baik saham maupun uang. KPEI juga merupakan lembaga yang turut menentukan arah perkembangan pasar modal Indonesia. KPEI bisa dianggap sebagai kasir yang menghitung kewajiban dan hak dari pembeli, KPEI sebagai penyeimbang yang akan memberikan rasa aman bagi pembeli dan penjual efek untuk penyelesaian transaksi di Bursa.

Fungsi kliring yang dilakukan KPEI adalah untuk menentukan hak dan kewajiban yang harus diselesaikan oleh pembeli dan penjual efek, melalui makeanisme kliring ini penyelesaian transaksi bursa menjadi sangat efisien. Sedangkan fungsi penjaminan KPEI dalam penyelesaian transaksi bursa adalah memastikan dipenuhinya semua hak dari pembeli dan penjual efek, jadi jika terjadi kegagalan penyelesaian kewajiban dari pembeli maupun penjual efek, akan tetap terjamin pelaksanaannya

\section{KSEI (Kustodian Sentral Efek Indonesia)}

PT Kustodian Sentral Efek Indonesia (KSEI) merupakan Lembaga Penyimpanan dan Penyelesaian (LPP) di Pasar Modal Indonesia yang menyediakan layanan jasa Kustodian sentral dan penyelesaian transaksi Efek yang teratur, wajar, dan efisien, sesuai amanat Undang-Undang 
Nomor 8 Tahun 1995 tentang Pasar Modal. Didirikan di Jakarta pada 23 Desember 1997 dan memperoleh izin usaha pada 11 November 1998.

KSEI mempunyai fungsi utama sebagai penyimpanan dan penyelesaian di pasar modal Indonesia. Peranan KSEI selain sebagai lembaga penyimpanan dan penyelesaian di bursa efek indonesia, KSEI melakukan pengembangan dengan mengubah saham yang dahulunya dalam bentuk warkat menjadi bentuk tanpa warkat (scriples trading), yang tanda bukti kepemilikan efeknya tidak lagi dalam bentuk fisik sertifikat efek, melainkan dalam bentuk rekening efek. Selain itu KSEI juga mengimplementasikan Single Investor Identity di pasar modal Indonesia, pemisahan rekening dana dan efek milik investor dengan perusahaan efek

\section{Perusahaan Efek}

Pihak yang melakukan kegiatan usaha dan memiliki izin Otoritas Jasa Keuangan sebagai Penjamin Emisi Efek (PEE), Perantara Pedagang Efek (PPE), dan atau Manajer Investasi (MI). Lebih dikenal sebagai perusahaan sekuritas.

a. Penjamin Emisi Efek (underwriter). Dalam rangka memenuhi syarat Initial Public Offering (IPO), peran penjamin emisi sangat fital. Underwriter merupakan pihak yang membuat kontrak dengan emiten untuk melakukan Penawaran Umum bagi kepentingan emiten dengan atau tanpa kewajiban untuk membeli kembali sisa efek yang tidak terjual (Robert Ang, 1995).

b. Perantara Pedagang Efek (Broker- Dealer). Mekanisme perdagangan efek di bursa efek tidak dapat langsung terjadi antara investor beli dan investor jual, melainkan prosesnya harus melewati perantara yang disebut dengan Wakil Perantara Perdagangan Efek (WPPE), melaksanakan setiap order beli atau order jual dari para nasabahnya dan mendapatkan jasa perantara efek.

c. Manajer Investasi (Fund Manager, Investment Company). Manajer investasi merupakan perusahaan efek yang 
melakukan usaha sebagai pengumpul dana serta mengelola dana untuk investasi sesuai perjanjian dengan investor (Djiptono Darmaji dan Hendy Fakrudin. 2011). Sedangkan (Robert Ang, 1995) mendefinikan manajer investasi sebagai pihak yang kegiatan usahanya mengelola portofolio efek untuk par nasabah atau mengelola portofolio investasi kolektif untuk sekelompok nasabah, kecuali perusahaan asuransi, dana pensiun dan bank yang melakukan sendiri kegiatan usahanya berdasarkan peraturan perundangan yang berlaku.

\section{Lembaga Penunjang}

a. Biro Administrasi Efek (BAE) : menyelenggarakan administrasi perdagangan Efek, baik pada saat pasar perdana maupun pada pasar sekunder. BAE menyediakan jasa kepada Emiten dan Perusahaan Publik dalam bentuk pencatatan dan pemindahan kepemilikan Efek. Tugas dan tanggung jawab Biro Administrasi Efek adalah mengadministrasikan, mneyimpan dan memelihara catatan, pembukuan datadan keterangan tertulis yang berhubungan dengan emiten. Biro Administrasi Efek wajib menjaga sebaik-baiknya setiap efek maupun pencatatan dalam pengelolaan dan wajib membuat salinan dari catatan yang disimpan dalam tempat terpisah.

b. Kustodian adalah pihak yang memberikan jasa penitipan Efek dan harta lain yang berkaitan dengan Efek serta jasa lain, termasuk menerima dividen, bunga, dan hak-hak lain, menyelesaikan transaksi Efek, dan mewakili pemegang rekening yang menjadi nasabahnya (Tandeilin Eduardus, 2017). Kustodian selaku pihak yang menyimpan efek harus dapat menjaga kerahasiaan para nasabah, kustodian dan pihak yang terafiliasinya dilarang memberikan keterangan mengenai rekening efek kepada pihak manapun, kecuali: pihak yang ditunjuk secara tertulis oleh pemegang rekening atau ahli waris pemegang rekening; Polisi, Jaksa atau Hakim untuk 